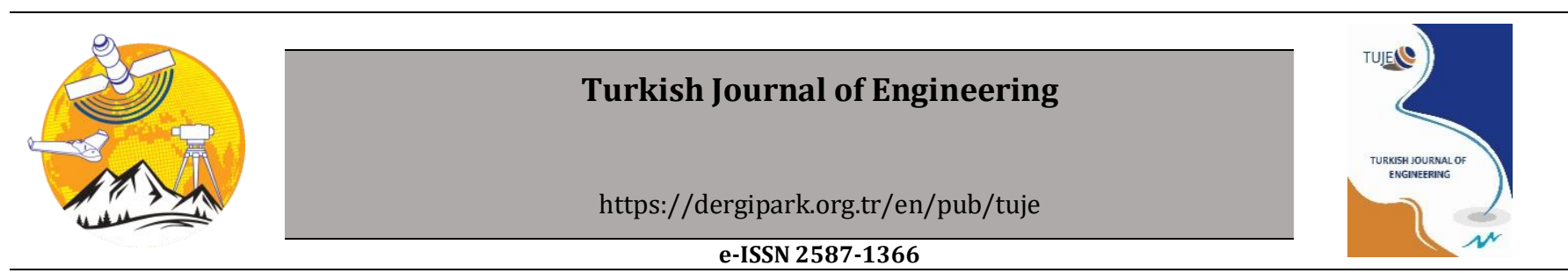

\title{
Valorization of banana pseudostem: endoxylanase production by Streptomyces sp. SH5027 using statistical approaches and its characterization and application in bread making
}

\author{
Ali Osman Adıgüzel ${ }^{*}$ (i) \\ Ondokuz Mayıs University, Faculty of Science and Letters, Department of Molecular Biology and Genetics, Samsun, Turkey
}

\author{
Keywords \\ Banana pseudostem \\ Endoxylanase \\ Streptomyces \\ RSM \\ Bread making
}

\begin{abstract}
The present study aimed to achieve a cost-effective production of endoxylanase by Streptomyces sp. SH5027 using banana pseudostem with the combination of conventional and statistical optimization and to determine the biochemical properties of the enzyme and its effect on bread making. Enzyme production increased from $7.25 \mathrm{U} / \mathrm{mL}$ to $50.21 \mathrm{U} / \mathrm{mL}$ as a result of the optimization studies. The enzyme was stable at $50-75^{\circ} \mathrm{C}$ and also retained more than $50 \%$ of its activity at $\mathrm{pH} 5.0-9.0$ for an hour at optimum temperature. The calculated $K_{m}$ value for the purified enzyme was $1.689 \mathrm{mg} / \mathrm{mL}$.min, while the $V_{\max }$ value was 23.17 $\mu \mathrm{mol} / \mathrm{min} . \mathrm{mg}$. The specific volume of the bread increased $9.6 \%, 12.8 \%$, and $16.8 \%$ when 200 $\mathrm{U}, 300 \mathrm{U}$, and $400 \mathrm{U}$ endoxylanase was added to the flour per kg, respectively. This study is the first to be conducted on the statistical optimization of endoxylanase production using banana pseudostem.
\end{abstract}

\section{INTRODUCTION}

In the last decade, agricultural wastes have increased day by day as a result of the agricultural economy developed in parallel to unrelenting population growth. Landfilling and burning, which are commonly used processes for the disposal of agricultural wastes, result in environmental and economic damages as they release toxic and/or hazardous compounds into the environment. Therefore, the interest in the conversion of agricultural wastes including wheat straw, corn stover, rice husk, sugar cane bagasse, and banana pseudostem, into value-added products has increased considerably due to the need to ensure sustainability in environmental management, bio-economy, and crops and food security (Adıgüzel and Tunçer 2017a; Adıgüzel 2020).

Bananas are one of the most important agroindustrial crops worldwide with about 114 million tons of production and 18.1 million tons of export volume in 2017 according to the Food and Agriculture Organization (FAO) (Fao 2017). Although bananas are mainly cultivated in the tropical and sub-tropical regions of
Latin America, Asia and Africa, they can be produced all over the world. In the Mediterranean region of Turkey, approximately 200-300 thousand tons of bananas are produced every year. With the harvest of each ton of banana, approximately 3 tons of pseudostems, 0.16 tons of stems, 0.48 tons of leaves and 0.44 tons of skin residues are generated (Padam et al. 2014). These wastes, which are either discharged, left to dry on fields or burned by farmers, pollute the atmosphere, contaminate groundwater and cause the spread of plant pathogens such as Thielaviopsis paradoxa, Colletotrichum musae and Fusarium verticillioides (Alvindia and Natsuaki 2009). Furthermore, banana wastes mostly end up in the sea due to extreme winds and rain in winter since, in Turkey, most of the areas cultivated with banana are sloping lands. Thus, due to the pollution of the sea, economic loss occurs in these regions which have a significant tourism potential.

Banana pseudostems consist of $25-30 \%$ cellulose, 20 25\% hemicelluloses, and 10-15\% lignin (Gabhane et al. 2014). On account of its relatively low lignin content, it is considered as a potential feedstock in green chemistry 
applications such as the production of bioethanol, carboxymethylcellulose (CMC), bioactive compounds, and the absorbent of xenobiotics (Padam et al. 2014). Furthermore, banana pseudostems can be used as a cheap and efficient inducer for the production of lignocellulolytic enzymes such as cellulases and xylanases with microbial fermentation methods. Xylanases are a group of enzymes that catalyze the hydrolysis of xylan, which is the second most abundant polysaccharide, after the cellulose of lignocellulosic biomass. The endo-1,4- $\beta$-xylanase (1,4- $\beta$-D-xylan xylohydrolases, EC 3.2.1.8) otherwise known as endoxylanase, releases xylooligosaccharides, xylobiose, and xylose by random breakage of the $\beta-1,4$ glycosidic bonds in the xylan chain. They have a huge commercial potential as they can be used in various industrial applications such as the bleaching of kraft pulps, deinking of paper, clarification of fruit juices and wines, saccharification of hemicelluloses, improvement of animal feed digestibility, and extraction of oils from plants or vegetables. They are also used for improving the rheological properties and machinability of dough as well as the shelf life and nutritional quality of bread (Walia et al. 2017). Until today, very few studies have been conducted on xylanase production using banana pseudostems. Vieira et al. (2007) reported that Clostridium thermocellum produced from $5.14 \mathrm{U} / \mathrm{mL}$ xylanase after being grown in a medium containing $2 \%$ banana pseudostem. In their study, Shah et al. (2005) reported that Phylosticta spp. MPS-001 could produce using laccase, lignin peroxidase, xylanase and cellulase on banana pseudostem through solid-state fermentation.

One of the most significant challenges in green chemistry applications is the high process cost. It is seen that the use of cheap inducers alone is not sufficient to reduce the cost of value-added products such as endoxylanase. However, this can be reduced with process optimization through conventional and/or model-based statistical approaches. One-factor-at-time (OFAT), a conventional method in which only one independent variable is tested in each step, is timeconsuming, especially in evaluating the effect of a large number of variables on enzyme production (Yabalak et al. 2017). Alternatively, Placket Burman Design (PBD) and Response Surface Methodology-Central Composite Design (RSM-CCD) provide a rapid selection of the most significant independent variables and an evaluation of the combined effect of the selected variables on the result, respectively. Su et al. (2011) reported that the xylanase yield of Thermomyces lanuginosus SDYKY-1 increased approximately 2.4-fold through PBD and RSMCCD in a fermentation medium prepared using corncobs and soybeans as carbon sources. Kumar and Satyanarayana (2012) reported that Bacillus halodurans produced 7.35-fold more xylanase using wheat bran as the carbon source after the optimization of the process by the same approach. Sharma and Bajaj (2018) achieved a 1.92-fold enhancement in xylanase production from Aspergillus terreus S9 using model-based statistical approaches. To our knowledge, endoxylanase production using banana pseudostem has not yet been studied through model-based statistical approaches.
In the present study, actinobacterial strains were selectively isolated from soil contaminated with banana plant wastes and screened by quantitative and qualitative analysis for endoxylanase production using banana pseudostem as the carbon source. The process conditions were optimized by (One Factor at Time) OFAT while PBD and RSM-CCD were used for the optimization of the composition of the medium. Endoxylanase produced under optimum condition was purified by ion exchange and gel filtration chromatography methods. Subsequently, its biochemical properties were detected. Finally, potential application of enzyme in bread making were studied.

\section{METHOD}

\subsection{Isolation and Identification of Microorganisms}

A total of 10 soil samples were collected from different areas contaminated with banana wastes in Erdemli (Mersin/Turkey) and stored at $4^{\circ} \mathrm{C}$. The analysis of the soils and the isolation of bacteria were initiated within $12 \mathrm{~h}$ (hours) after sampling. The air-dried soil samples were suspended in distilled water at 1:2.5 and $1: 5(\mathrm{w} / \mathrm{v}$, soil/water) ratios for $\mathrm{pH}$ and conductivity analysis. After the suspensions were agitated at $150 \mathrm{rpm}$ for $30 \mathrm{~min}$, their $\mathrm{pH}$ and conductivity were measured by $\mathrm{pH} /$ Conductivity Meter (Hanna HI-2300) (Houfani et al. 2017). Gravimetric water and organic matter contents were determined by measuring weight loss in crude soils incubated at $105{ }^{\circ} \mathrm{C}$ for $48 \mathrm{~h}$ in an oven and water-free soils incubated at $550{ }^{\circ} \mathrm{C}$ for $16 \mathrm{~h}$ in a muffle furnace, respectively (Houfani et al. 2017).

Before bacterial isolation, the soil samples were pretreated with incubation at $50{ }^{\circ} \mathrm{C}$ for $1 \mathrm{~h}$ and serially diluted in $1 / 4$ ringer solutions $\left(10^{-2}-10^{-7}\right) .100 \mu \mathrm{L}$ of the diluted solution $\left(10^{-4}-10^{-6}\right)$ was spread on a modified (International Streptomyces Project 4) ISP4 medium containing birchwood xylan instead of soluble starch $(\mathrm{pH}$ $7.0 \pm 0.2$ ). The colonies that had different structures, shapes, and colors were picked and purified on a (International Streptomyces Project 2) ISP2 medium. All isolates were maintained on an ISP2 medium slant at +4 ${ }^{\circ} \mathrm{C}$ and in $20 \%$ glycerol at $-20{ }^{\circ} \mathrm{C}$, respectively.

\subsection{Screening of Xylanolytic Isolates}

For the selection of the most efficient endoxylanase producers, the isolates were screened by quantitative and qualitative analysis. The pure isolates were spot inoculated on a modified ISP4 medium and then incubated at $30{ }^{\circ} \mathrm{C}$ for 4 days for quantitative analysis. At the end of the incubation period, the surface of the plates was coated with $1 \%(\mathrm{w} / \mathrm{v}$ ) Congo red solution for $15 \mathrm{~min}$ and then washed using $1 \mathrm{M} \mathrm{NaCl}$ three times to remove any excess and unbound dye. A slight yellow hydrolysis zone around the colony indicates that the isolate produces xylanolytic enzymes. Subsequently, the extracellular endoxylanase production in $50 \mathrm{~mL}$ unoptimized fermentation medium (UFM: $10 \mathrm{~g} / \mathrm{L}$ banana pseudostem, $1 \mathrm{~g} / \mathrm{L}$ peptone, $1 \mathrm{~g} / \mathrm{L}$ yeast extract, $1 \mathrm{~g} / \mathrm{L}$ $\mathrm{KNO}_{3}, 0.5 \mathrm{~g} / \mathrm{L} \mathrm{KH}_{2} \mathrm{PO}_{4}, 0.5 \mathrm{~g} / \mathrm{L} \mathrm{MgSO}_{4}, 0.3 \mathrm{~g} / \mathrm{L} \mathrm{CaCl}_{2}, 3 \mathrm{~g} / \mathrm{L}$ $\mathrm{NaCl}$ and $0.6 \mathrm{~g} / \mathrm{L}$ tween 80 ) was assessed. Endoxylanase production was performed in a $250 \mathrm{~mL}$ Erlenmeyer flask 
under shaking condition at $160 \mathrm{rpm}$ and $30^{\circ} \mathrm{C}$ for 4 days after inoculation of strain.

\subsection{Identification of Strain}

The strain used for endoxylanase production was identified based on 16S rRNA gene sequences. The strain was grown in an ISP2-liquid medium at $30{ }^{\circ} \mathrm{C}$ and 160 rpm for 3 days. The cells were recovered by centrifugation (10000 $\mathrm{g}, 5 \mathrm{~min})$. DNA isolation was carried out using the AMBRD DNA isolation kit as described by the manufacturer. The $16 \mathrm{~S}$ rRNA gene was amplified using 27 forward (5'-AGA GTT TGA TCA TCA TGG CTC AG) and 1492 reverse (5'-TAC GGC TAC CTT GTT ACG ACT T) primers according to Adigüzel and Tunçer (2016). Subsequently, the sequences data of the $16 \mathrm{~S}$ rRNA gene were compared with the sequences in the National Center for Biotechnology Information (NCBI) database by BLAST to construct a phylogenetic tree using MEGA 6 software.

\subsection{Preparation of Inoculums}

One $\mathrm{mL}$ of $1 / 4$ ringer solution was poured on a 15 day-old culture grown on an ISP2 medium. Subsequently, spore suspension was prepared by gently shaking the culture plate for $1 \mathrm{~min}$ (minute). After counting, $200 \mu \mathrm{L}$ of diluted spore suspension containing approximately $10^{6} \mathrm{spore} / \mathrm{mL}$ was used as inoculum.

\subsection{Estimation of Extracellular Total Protein and Endoxylanase Activity}

The supernatant obtained with the centrifugation of the culture $(10000 \mathrm{~g}, 5 \mathrm{~min})$ was used as a crude enzyme. The total protein in the crude enzyme was estimated using bovine serum albumin as standard (Bradford 1976). Endoxylanase activity was determined by the dinitrosalicylic acid (DNS) method of Miller with slight modification (Miller 1959). The reaction mixture consisting of supernatant and $1 \%$ birchwood xylan solution prepared in a phosphate buffer $(100 \mathrm{mM}, \mathrm{pH}$ 7.0) was incubated at $30{ }^{\circ} \mathrm{C}$ for $10 \mathrm{~min}$. The reaction was terminated with the addition of the DNS solution. The mixture was kept in boiling water for $10 \mathrm{~min}$. Subsequently, the amount of reducing sugar released was calculated by measuring the absorbance at $540 \mathrm{~nm}$. A unit (U) of enzyme activity is defined as the amount of endoxylanase required to catalyze the release of $1 \mu \mathrm{mol}$ of xylose equivalent per min at $30^{\circ} \mathrm{C}$ (Adıgüzel and Tunçer 2017b).

\subsection{Estimation of Extracellular Total Protein and Endoxylanase Activity Selection of Cultural Conditions by OFAT for Endoxylanase Production}

The Placket Burman matrix was developed using Design Expert 7.0. software (Stat-Ease, Minneapolis, MN, USA) to determine the most important variables on endoxylanase production. As shown in table 1, 9 independent variables including banana pseudostem (A), peptone (B), yeast extract (C), $\mathrm{KNO}_{3}$ (D), $\mathrm{MgSO}_{4}(\mathrm{E})$, $\mathrm{KH}_{2} \mathrm{PO}_{4}(\mathrm{~F}), \mathrm{CaCl}_{2}(\mathrm{G}), \mathrm{NaCl}(\mathrm{H})$ and Tween $80(\mathrm{~J})$ were tested in two levels: +1 for high level and -1 for low level. A total of 12 experimental runs were conducted in triplicate and the average endoxylanase activities were taken as responses. The significance of the statistical model was determined using ANOVA. The effects of each independent variable were calculated according to the Equation 1.

$$
E x_{i}=\left(\sum M_{\dot{\mathrm{I}}}^{+}-\sum M_{\dot{\mathrm{I}}}^{-}\right) / N(1)
$$

where, $E x_{i}$ is the effect of a variable, $M_{\dot{\mathrm{I}}}^{+}$and $M_{\dot{\mathrm{I}}}^{-}$are the responses of the experimental runs at the high and low levels of each variable, respectively, and $\mathrm{N}$ is the total number of runs.

\subsection{Optimization of Parameters by RSM-CCD}

RSM-CCD was employed to optimize the three most important variables identified by $\mathrm{PB}$ design, and to elucidate the relationship between these variables for enhancing endoxylanase production. The construction of the design matrix was carried out using Design Expert 7.0 software (Stat-Easy). The variables denoted (banana pseudostem), (yeast extract) and (tween 80) were analyzed at 5 coded levels $(-\alpha,-1,0,+1,+\alpha)$ as shown in table 2. Based on the design matrix, a total of 20

Table 1. Levels of variables in Plackett Burman design matrix along with experimental and predicted endoxylanase production

\begin{tabular}{|c|c|c|c|c|c|c|c|c|c|c|c|}
\hline \multirow[t]{2}{*}{ Run } & \multicolumn{9}{|c|}{ Variables $(\mathrm{g} / \mathrm{L})$} & \multicolumn{2}{|c|}{ Endoxylanase production $(\mathrm{U} / \mathrm{mL})$} \\
\hline & A & B & $\mathrm{C}$ & $\mathrm{D}$ & $\mathrm{E}$ & $\mathrm{F}$ & G & $\mathrm{H}$ & $\mathrm{J}$ & Experimental & Predicted \\
\hline 1 & 20 & 0.5 & 0.5 & 3 & 1 & 0.2 & 0.4 & 5 & 0.1 & 14.20 & 14.08 \\
\hline 2 & 20 & 3 & 3 & 1 & 0.2 & 1 & 0.4 & 5 & 0.1 & 19.36 & 19.21 \\
\hline 3 & 4 & 0.5 & 0.5 & 3 & 0.2 & 1 & 0.4 & 1 & 0.5 & 10.04 & 9.89 \\
\hline 4 & 4 & 3 & 3 & 3 & 0.2 & 0.2 & 0.1 & 5 & 0.1 & 12.14 & 12.26 \\
\hline 5 & 20 & 0.5 & 0.5 & 1 & 1 & 1 & 0.1 & 1 & 0.1 & 16.46 & 16.61 \\
\hline 6 & 4 & 3 & 0.5 & 1 & 0.2 & 0.2 & 0.1 & 1 & 0.1 & 9.30 & 9.42 \\
\hline 7 & 4 & 0.5 & 3 & 3 & 1 & 0.2 & 0.4 & 1 & 0.1 & 13.24 & 13.12 \\
\hline 8 & 20 & 3 & 3 & 1 & 0.2 & 1 & 0.4 & 1 & 0.5 & 24.94 & 24.81 \\
\hline 9 & 4 & 0.5 & 0.5 & 1 & 1 & 0.2 & 0.4 & 5 & 0.5 & 11.32 & 13.31 \\
\hline 10 & 4 & 3 & 3 & 1 & 1 & 1 & 0.1 & 5 & 0.5 & 13.16 & 13 \\
\hline 11 & 20 & 0.5 & 3 & 3 & 1 & 0.2 & 0.1 & 1 & 0.5 & 23.84 & 23.99 \\
\hline 12 & 20 & 3 & 0.5 & 3 & 0.2 & 0.2 & 0.1 & 5 & 0.5 & 16.60 & 16.72 \\
\hline
\end{tabular}


experimental runs involving 6 centers, 6 axials, and 8 factorial points were performed in triplicate. Average endoxylanase production was taken as a response. To predict endoxylanase production, results from each experimental run in the design matrix were fitted to the following second order polynomial Equation 2 .

$$
\begin{gathered}
Y_{\mathrm{i}}=b_{0}+b_{1} X_{1}+b_{2} X_{2}+b_{3} X_{3}+b_{11} X_{1}^{2}+b_{22} X_{2}^{2}+ \\
b_{33} X_{3}^{2}+b_{12} X_{1} X_{2}+b_{23} X_{2} X_{3}+b_{13} X_{1} X_{3}(2)
\end{gathered}
$$

where, $Y_{\mathrm{I}}$ is the predicted endoxylanase production by Streptomyces sp. SH5027, $X_{1}, X_{2}, X_{3}$ are the independent variables, $b_{0}$ is the offset term, $b_{1}, b_{2}, b_{3}$ are the linear effects, $b_{11}, b_{22}, b_{33}$ are the squared effects and $b_{12}, b_{23}, b_{13}$ are the interaction terms.

Table 2 Levels of variables tested in RSM-CCD

\begin{tabular}{lccccc}
\hline Variables & \multicolumn{5}{c}{ Coded levels } \\
\cline { 2 - 6 } & $-\alpha$ & -1 & 0 & +1 & $+\alpha$ \\
\cline { 2 - 6 } $\mathrm{X}_{1}(\mathrm{~g} / \mathrm{L})$ & 4.00 & 7.24 & 12.00 & 16.76 & 20.00 \\
$\mathrm{X}_{2}(\mathrm{~g} / \mathrm{L})$ & 1.00 & 2.01 & 3.50 & 4.99 & 6.00 \\
$\mathrm{X}_{3}(\mathrm{~g} / \mathrm{L})$ & 0.20 & 0.36 & 0.60 & 0.84 & 1.00 \\
\hline
\end{tabular}

\subsection{Purification of Endoxylanase for Characterization}

Streptomyces sp. SH5027 was cultivated in the optimized fermentation medium under optimum cultural conditions. All purification steps were carried out at approximately $4{ }^{\circ} \mathrm{C}$. The culture supernatant was used as the crude enzyme after centrifugation at $10000 \mathrm{~g}$ for $5 \mathrm{~min}$. The crude enzyme was both concentrated and fractionated with a $30 \mathrm{kDa}$ molecular weight cut-off membrane using pressure based Amicon stirred ultrafiltration cells. Proteins higher than $50 \mathrm{kDa}$ in fraction were separated with $50 \mathrm{kDa}$ molecular weight cut-off membrane using the same method. Subsequently, a partially purified enzyme was dialyzed against $20 \mathrm{mM}$ Tris-HCl (pH 8.0) and then loaded onto DEAE Sephadex A-50 anion-exchange column $(2.6 \times 10 \mathrm{~cm})$ equilibrated with $20 \mathrm{mM}$ Tris- $\mathrm{HCl}(\mathrm{pH} 8.0)$. The elution of the bound proteins was performed with a linear gradient of $0-1 \mathrm{M}$ $\mathrm{NaCl}$ in the same buffer containing a flow rate of 0.75 $\mathrm{mL} / \mathrm{min}$. The endoxylanase activity and protein concentration of each fraction $(5 \mathrm{~mL})$ were estimated by the DNS method and measuring absorbance at $280 \mathrm{~nm}$, respectively. The fractions showing high endoxylanase activity were pooled, concentrated and dialyzed for further studies. The purity of the enzyme was shown on acrylamide gel by sodium dodecyl sulfate polyacrylamide gel electrophoresis (SDS-PAGE) (Adıgüzel and Tunçer, 2016).

\subsection{Characterization of Endoxylanase and Its Application in Baking}

The enzyme assay was carried out by varying only one factor at a time to determine the biochemical properties of endoxylanase from Streptomyces sp. SH5027. The reaction was carried out at different temperatures $\left(20-80^{\circ} \mathrm{C}\right)$ in a $50 \mathrm{mM}$ phosphate buffer (pH 7.0) to determine the optimum temperature for endoxylanase activity. The optimum $\mathrm{pH}$ was detected by assaying the endoxylanase activity in the various buffers
(50 mM) including a citrate buffer ( $\mathrm{pH}$ 4.0-6.0), a phosphate buffer ( $\mathrm{pH}$ 6.0-7.5), and a Tris-HCl buffer $(\mathrm{pH}$ 7.5-9.0) at $45^{\circ} \mathrm{C}$. The measured maximum activity was found to be $100 \%$. The thermostability of the enzyme was evaluated by the pre-incubation of the enzyme (1-12 h) in a $50 \mathrm{mM}$ phosphate buffer ( $\mathrm{pH}$ 6.5) at various temperatures ranging from 40 to $80^{\circ} \mathrm{C}$. The stability of endoxylanase at different $\mathrm{pH}$ values ranging from 4.5 to 10.0 was investigated by the pre-incubation of the enzyme in various buffers $(50 \mathrm{mM})$ described above at $45^{\circ} \mathrm{C}$. To investigate the storage time of the enzyme, the endoxylanase solution prepared in a $50 \mathrm{mM}$ phosphate buffer ( $\mathrm{pH}$ 6.5) was the kept at -20 and $+4{ }^{\circ} \mathrm{C}$ for 180 days. The initial enzyme activity was accepted as $100 \%$.

The endoxylanase was pre-incubated with $5 \mathrm{mM}$ metal ions $\left(\mathrm{Mn}^{+2}, \mathrm{Mg}^{+2}, \mathrm{Ca}^{+2}, \mathrm{Hg}^{+2}, \mathrm{Zn}^{+2}\right.$, and $\left.\mathrm{Cu}^{+2}\right), 10 \%$ organic solvents (ethanol, methanol, isopropanol, dimethyl sulfoxide, ethyl acetate, and dimethylformamide) and $5 \mathrm{mM}$ inhibitors (ethylenediaminetetraacetic acid, sodium dodecyl sulfate, 1,4-dithiothreitol, and mercaptoethanol,) in a phosphate buffer ( $50 \mathrm{mM}$, pH 6.5) for 30, 60 and $120 \mathrm{~min}$, respectively. Subsequently, residual endoxylanase activity was measured at $45{ }^{\circ} \mathrm{C}$. The activity of endoxylanase pre-incubated in an additive-free buffer under the same condition was accepted to be $100 \%$.

To investigate the substrate specificity of the enzyme, various substrates (beechwood xylan, oat spelt xylan, carboxymethyl cellulose, filter paper, soluble starch, and citrus pectin) were used instead of birchwood xylan in the activity assay performed under optimum temperature and $\mathrm{pH}$. The activity against birchwood xylan was found to be $100 \%$. The kinetic study was performing the assaying the enzyme using a range of birchwood xylan concentration from 0.5 to $20 \mathrm{mg} / \mathrm{mL}$ under optimum condition. A Linewaever-Burk plot illustrating the Michaelis constant $\left(K_{m}\right)$ and the specific activity $\left(V_{\max }\right)$ was generated using Hyper32 software.

Within the scope of the present study, breads were produced at a local bakery (Karadeniz Bakery) in Adana, Turkey. The dough was prepared conventionally by adding $20 \mathrm{~g} \mathrm{NaCl}(\mathrm{w} / \mathrm{w}), 40 \mathrm{~g}$ yeast (w/w), and $1200 \mathrm{~mL}$ tap water supplemented with endoxylanase (100-400 U) for $1 \mathrm{~kg}$ flour. After the dough was mixed at room temperature for $120 \mathrm{~min}$, it was divided into pieces of $200 \mathrm{~g}$, hand-rounded and left to rest on a tray for 120 min. Subsequently, the dough was baked at $300{ }^{\circ} \mathrm{C}$ for 15 min. The breads were cooled for $2 \mathrm{~h}$ before determining their specific volumes. The specific volume of the dough prepared without the enzyme was accepted as $100 \%$.

\section{RESULTS and DISCUSION}

\subsection{Isolation and Selection of Xylanolytic Strains}

There were no significant differences in the $\mathrm{pH}$, conductivity, gravimetric water content, or organic matter content of the soil samples collected from 10 different locations (data was not shown). The appropriate dilutions of the soil samples, contaminated with banana wastes, were plated on a modified ISP-4 medium. Out of approximately 180 bacterial colonies that could grow on the medium, 48 were isolated 
considering the morphological differences (shape and color). Their ability to produce xylanolytic enzymes on the same medium was screened by Congo red staining which is a low cost and practical method. A total of 28 strains showed xylanolytic activity which was indicated by the appearance of a slight yellow zone of hydrolysis around the colonies (figure 1). Among them, the isolate SH5027 exhibited the highest endoxylanase production (7.25 U/mL) with $30.16 \mathrm{U} / \mathrm{mg}$ specific activity in unoptimized fermentation medium. Therefore, the isolate SH5027 was selected for further studies.
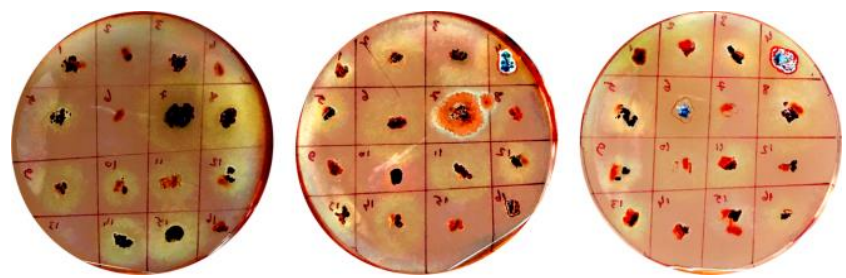

Figure 1. Screening of xylan production on agar plates. The slight yellow zone around the colony indicates that the strain can produce xylanolytic enzymes

\subsection{Molecular identification}

The partial 16S rRNA gene sequence (1210 bp) of the isolate SH5027 was analyzed by BLAST in NCBI. The sequence showed a $96.07 \%$ identity to those of Streptomyces almquistii NRRL B-1685, Streptomyces althioticus strain 12740, Streptomyces griseoincarnatus NBRC 12871, Streptomyces labedae NBRC 15864 and Streptomyces variabilis NRRL B-3984. The 16 S rRNA gene sequences from the other related type strains, which were shown in the phylogenetic tree, exhibited less than $96 \%$ sequence identity to the isolate SH5027 (figure 2). It was revealed that the isolate was closely related to the genus Streptomyces. Therefore, the isolate was classified into the Streptomyces genus and expressed as Streptomyces sp. SH5027. The polyphasic approach including chemotaxonomic, phenotypic, and genotypic characterizations of the isolate is required for a more detailed explanation of its taxonomic position.

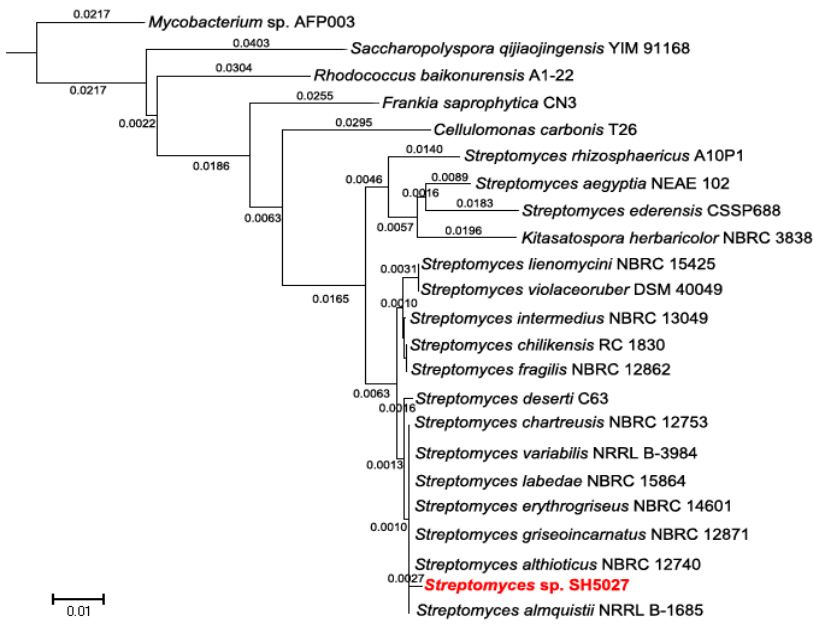

Figure 2. Phylogenetic tree showing the relationship between the isolate SH5027 and strain types. The tree was constructed based on their 16S rRNA gene sequences by MEGA6 software using neighbor-joining

\subsection{Selection of cultural conditions for endoxylanase production}

Cultural conditions such as temperature, initial $\mathrm{pH}$ of the medium and agitation speed highly influence enzyme production (Figure 3). The maximum endoxylanase production $(7.77 \mathrm{U} / \mathrm{mL})$ by Streptomyces sp. SH5027 was observed at $35{ }^{\circ} \mathrm{C}$. A relatively high enzyme titer was also detected at $25^{\circ} \mathrm{C}(6.15 \mathrm{U} / \mathrm{mL}), 30$ ${ }^{\circ} \mathrm{C}(7.28 \mathrm{U} / \mathrm{mL})$ and $40{ }^{\circ} \mathrm{C}(6.60 \mathrm{U} / \mathrm{mL})$. However, significant decreases in enzyme production were detected at $20{ }^{\circ} \mathrm{C}(2.64 \mathrm{U} / \mathrm{mL})$ and $45^{\circ} \mathrm{C}(1.05 \mathrm{U} / \mathrm{mL})$. The results of this study were in accordance with previous studies conducted on endoxylanase production by Streptomyces cuspidosporus (Maheswari and Chandra 2000), Streptomyces sp. isolated in India (Thomas et al. 2013) and Streptomyces sp. RCK-2010 (Kumar et al. 2012), which exhibited high endoxylanase production at $25-40{ }^{\circ} \mathrm{C}$. The effect of the initial $\mathrm{pH}$ of the medium on endoxylanase production was investigated at $35{ }^{\circ} \mathrm{C}$ and under a shaking condition of $160 \mathrm{rpm}$. The endoxylanase titer was found to be maximum when the initial $\mathrm{pH}$ of the medium was adjusted to $6.0(8.01 \mathrm{U} / \mathrm{mL})$. Enzyme production decreased slightly when the initial $\mathrm{pH}$ of the medium was increased to $7.0(7.59 \mathrm{U} \mathrm{U} / \mathrm{mL})$ and 8.0 $(6.46 \mathrm{U} / \mathrm{mL})$. At pH 5.0, enzyme production decreased in half $(4.36 \mathrm{U} / \mathrm{mL})$. The findings were in line with a previous study conducted by Porsuk et al. (2013). The test performed to determine the influence of agitation speed on endoxylanase production showed that high xylanase production occurred at 120-220 rpm. Any agitation speed beyond this range was not suitable for endoxylanase production. In addition, maximum endoxylanase production was recorded at $180 \mathrm{rpm}$ with 8.26 U/mL. The decrease in endoxylanase production under lower agitation speeds may be due to weak oxygen transfer, insufficient distribution of oxygen in Erlenmeyer flask and interaction between bacteria and banana pseudostem used as inducer.

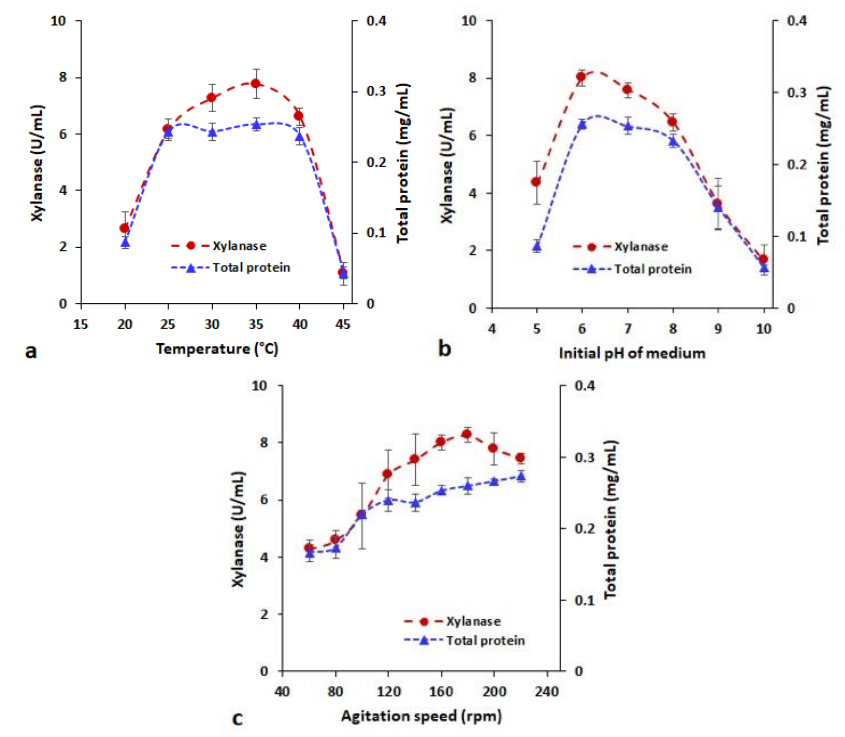

Figure 3. The effect of temperature (a), initial pH of the medium (b), and agitation speed (c) on endoxylanase production by Streptomyces sp. SH5027 as well as extracellular protein secretion 


\subsection{Selection Selection of the most important variables affecting endoxylanase production by PBD}

All experimental runs were performed at $35{ }^{\circ} \mathrm{C}$ and under a shaking condition of $180 \mathrm{rpm}$. The initial $\mathrm{pH}$ of the medium was adjusted to 6.0 before the experiments. The experimental results showed significant variation in endoxylanase production from $9.30 \mathrm{U} / \mathrm{mL}$ to 24.96 $\mathrm{U} / \mathrm{mL}$. The significance and adequacy of the model were analyzed using Fischer's test for analysis of variance (ANOVA). The calculated $F$-value (286.04) showed that the applied model was statistically significant. The $p$ value of 0.0035 was found to be at a 95\% confidence interval. The variability in endoxylanase production was detected to be $99.92 \%$ according to the determination coefficient $\left(R^{2}\right)$ value. Furthermore, the values of the adjusted coefficient (Adj- $\left.R^{2}\right)$ and the predicted coefficient (Pred- $R^{2}$ ) were calculated to be 0.9957 and 0.9721 , respectively, and were in reasonable agreement. The adequate precision values (Adeq-Precision) of 50.671 , which give the signal to noise ratio, also indicated that the model generated strong signals to design space. The model was fitted for endoxylanase production with the Equation 3.

$$
Y=+7.83694+0.48146 A+0.16067 B+
$$$$
0.95933 C-0.14167 D-0.22500 E-0.1277778 F-
$$

$0.75000 G-0.46083 H+3.17083 J(3)$

where $\mathrm{Y}$ is the predicted endoxylanase activity and A, B, C, D, E, F, G, H, and J are the coded values of the independent variables.

The regression analysis coefficient and the $t$-values of the variables, which are shown in table 3 , revealed that banana pseudostem, yeast extract, tween 80 , peptone, and $\mathrm{CaCl}_{2}$ had a positive effect on endoxylanase production by Streptomyces sp. SH5027, whereas $\mathrm{NaCl}$, $\mathrm{KH}_{2} \mathrm{PO}_{4}, \mathrm{KNO}_{3}$, and $\mathrm{MgSO}_{4}$ had a negative effect. Among the variables, banana pseudostem, yeast extract, tween 80 and $\mathrm{NaCl}$ were significant due to their confidence level which was above $95 \%(p<0.05)$. Furthermore, a Pareto chart was drawn to illustrate the order of importance of the variables and which variables are the most important for endoxylanase production (figure 4). The chart revealed that banana pseudostem was above the Bonferroni limit, which is almost certainly important, while those above the $t$-value limit, namely, yeast extract, tween 80 and $\mathrm{NaCl}$, are possibly important. Considering the previous studies which focused on the induction of enzyme secretion by lignocellulosic agricultural wastes, important variable was found to be yeast extract used as a nitrogen source. This may be due to the effects of various growth factors and essential amino acids in yeast extract on the growth of the Streptomyces sp. SH5027. Another very significant variable, tween 80 , may provide the rapid transportation of compounds such as enzymes and soluble inducers across the cell membrane (Ahamed and Vermette 2008). In conclusion, banana pseudostem, yeast extract and tween 80 were selected for further optimization studies by RSM-CCD.

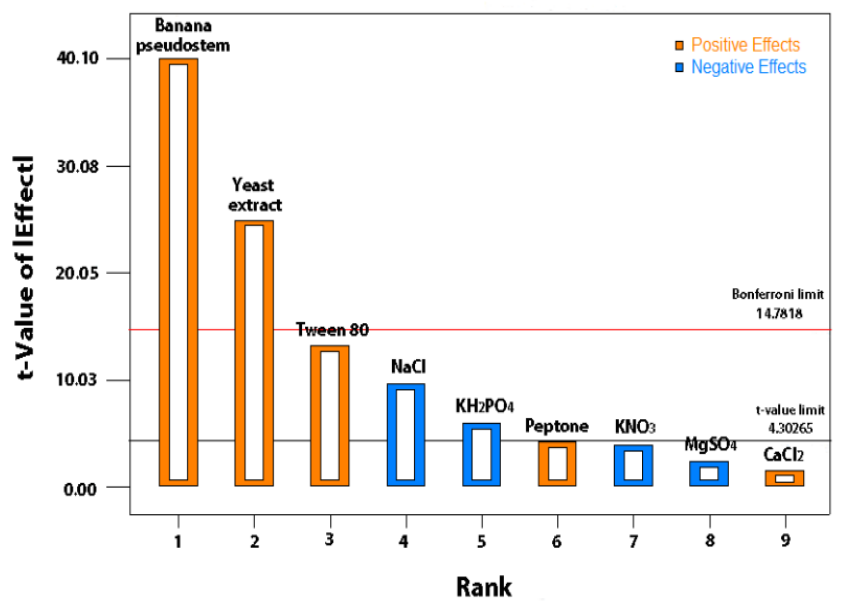

Figure 4. The Pareto chart illustrates the effects of independent variables on endoxylanase production by Streptomyces sp. SH5027

\subsection{RSM-CCD}

RSM-CCD was used to evaluate the interaction of the variables, selected based on the results from PBD, and to determine their optimal levels for endoxylanase production. The design matrix and experimental results, fitted with the second-order polynomial Equation 4, are presented in table 4.

$$
\text { Xylanase activity }\left(\frac{U}{m L}\right)=+3.10988+
$$

$4.73488 X_{1}-2.56680 X_{2}-15.16615 X_{3}-$ $0.70039 X_{1} X_{2}+0.32704 X_{1} X_{3}+11.80161 X_{2} X_{3}-$ $0.040353 X_{1}^{2}+0.62678 X_{2}^{2}--29.79754 X_{3}^{2}(4)$

where, $X_{1}, X_{2}, X_{3}$ are independent variables.

The highest and lowest experimental results were obtained from Run 20 (45.75 U/mL) and Run 11 (10.16 $\mathrm{U} / \mathrm{mL}$ ), respectively. The model fit was statistically assessed by ANOVA. It was revealed that the model with an $F$-value of 210.22 and $p$-value of $<0.0001$ was

Table 3. ANOVA results of the model constructed by Plackett Burman

\begin{tabular}{ccccccc}
\hline Variables (g/L) & Effect & Coefficient estimate & Standard error & Sum of square & F-value & p-value prob $>$ F \\
\hline A & 7.70 & 3.85 & 0.096 & 178.02 & 1608.7 & $0.0006^{*}$ \\
B & 0.80 & 0.40 & 0.096 & 1.94 & 17.49 & 0.0527 \\
C & 4.80 & 2.40 & 0.096 & 69.02 & 623.52 & $0.0016^{*}$ \\
D & 0.28 & 0.14 & 0.096 & 0.24 & 2.18 & 0.2782 \\
E & -0.45 & -0.22 & 0.096 & 0.61 & 5.49 & 0.1438 \\
F & -1.15 & -0.57 & 0.096 & 3.97 & 35.84 & $0.0268^{*}$ \\
G & -0.75 & -0.38 & 0.096 & 1.69 & 15.24 & 0.0598 \\
H & -1.84 & -0.46 & 0.048 & 10.19 & 92.08 & $0.0107^{*}$ \\
J & 2.54 & 1.27 & 0.096 & 19.30 & 174.38 & $0.0057^{*}$ \\
\hline
\end{tabular}

it is not surprising that banana pseudostem showed a strong effect (Sharma and Bajaj 2018). The second adequate and significant. Furthermore, the $R^{2}$-value calculated as 0.9947 proved the adequacy of the model 
and indicated that variability up to $99.47 \%$ in endoxylanase production could be explained by the model. The reasonable agreement between pred- $R^{2}$ (0.9712) and Adj- $R^{2}$ (0.9900) indicated a strong relationship between the experimental and predicted results. It was also determined that the signal was adequate and the model adapted to the results in a good methodology considering the Adeq-precision value of 63.754 and lack of fit $F$-value of 1.65 , respectively.

The ANOVA results of the terms are listed in table 5. Among the linear terms, banana pseudostem, yeast extract, and tween 80 were statistically significant. The quadratic effects of all the variables were also found to be significant. A strong interaction between banana pseudostem and yeast extract was found. Another strong interaction was also observed between yeast extract and tween 80. Furthermore, the results indicated that the banana pseudostem with the lowest $p$-value was the most important variable for endoxylanase production.

Three-dimensional (3D) response surface plots were generated to evaluate the influence of the variables on endoxylanase production by Streptomyces sp. that endoxylanase production enhanced with the increase in banana waste concentration at the low and middle levels of yeast extract. On the other hand, endoxylanse production decreased with the increase in banana pseudostem concentration at the high level of yeast extract. The increase in yeast extract levels resulted in the enhancement in enzyme production at the low level banana pseudostem. However, the fact that the yeast extract increased from the middle level to the high level showed a negative effect on endoxylanase production when the banana pseudostem was kept at the high level. This may be due to the Streptomyces sp. SH5027 preferred to use some degradation products of banana pseudostem as nitrogen sources during fermentation. Figure $5 \mathrm{~b}$ illustrates the increase in endoxylanase yield with an increasing level of banana pseudostem at all levels of tween 80. An increase or decrease in tween 80 concentration resulted in a decrease in endoxylanase production at all levels of the banana pseudostem. Enzyme production increased gradually with the increase in yeast extract

Table 4. Design matrix constructed by RSM-CCD, experimental and predicted results

\begin{tabular}{|c|c|c|c|c|c|c|c|c|c|c|c|}
\hline \multirow[t]{2}{*}{ Run } & \multicolumn{3}{|c|}{ Variables $(\mathrm{g} / \mathrm{L})$} & \multicolumn{2}{|c|}{$\begin{array}{c}\text { Endoxylanase production } \\
(\mathrm{U} / \mathrm{mL})\end{array}$} & \multirow[t]{2}{*}{ Run } & \multicolumn{3}{|c|}{ Variables $(\mathrm{g} / \mathrm{L})$} & \multicolumn{2}{|c|}{$\begin{array}{l}\text { Endoxylanase production } \\
\qquad(\mathrm{U} / \mathrm{mL})\end{array}$} \\
\hline & $X_{1}$ & $X_{2}$ & $X_{3}$ & Experimental & Predicted & & $X_{1}$ & $X_{2}$ & $X_{3}$ & Experimental & Predicted \\
\hline 1 & 12 & 3.5 & 0.6 & 30.41 & 30.71 & 11 & 7.24 & 2.01 & 0.84 & 10.16 & 10.72 \\
\hline 2 & 12 & 3.5 & 0.6 & 30.62 & 30.71 & 12 & 16.76 & 4.99 & 0.36 & 30.04 & 29.28 \\
\hline 3 & 12 & 3.5 & 0.6 & 30.33 & 30.71 & 13 & 12 & 3.5 & 0.6 & 32.09 & 30.71 \\
\hline 4 & 7.24 & 4.99 & 0.6 & 30.04 & 29.28 & 14 & 12 & 3.5 & 0.2 & 27.41 & 28.22 \\
\hline 5 & 12 & 3.5 & 0.6 & 30.42 & 30.71 & 15 & 16.76 & 2.01 & 0.84 & 19.05 & 18.90 \\
\hline 6 & 4 & 3.5 & 0.6 & 15.53 & 16.03 & 16 & 12 & 1 & 0.6 & 33.74 & 33.38 \\
\hline 7 & 7.24 & 2.01 & 0.36 & 23.15 & 22.51 & 17 & 12 & 6 & 0.6 & 35.22 & 35.87 \\
\hline 8 & $\begin{array}{c}16.7 \\
6\end{array}$ & 4.99 & 0.84 & 35.22 & 35.66 & 18 & 12 & 3.5 & 1 & 24.18 & 23.66 \\
\hline 9 & 7.24 & 4.99 & 0.84 & 30.95 & 30.44 & 19 & 12 & 3.5 & 0.6 & 30.42 & 30.71 \\
\hline 10 & 20 & 3.5 & 0.6 & 40.43 & 40.21 & 20 & 16.76 & 2.01 & 0.36 & 45.75 & 46.05 \\
\hline
\end{tabular}

Table 5. The ANOVA results of the terms used in construction of response surface by CCD

\begin{tabular}{|c|c|c|c|c|c|}
\hline Model terms & $\begin{array}{l}\text { Coefficient } \\
\text { estimate }\end{array}$ & Sum of square & Mean Square & $F$-value & $p$-value prob $>\mathrm{F}$ \\
\hline Model & & 1162.40 & 129.16 & 210.22 & $<0.0001^{*}$ \\
\hline$X_{1}$ & 7.19 & 705.77 & 705.77 & 1148.75 & $<0.0001^{*}$ \\
\hline$X_{2}$ & 0.74 & 7.45 & 7.45 & 12.13 & $0.0059^{*}$ \\
\hline$X_{3}$ & -1.35 & 25.04 & 25.04 & 40.76 & $<0.0001^{*}$ \\
\hline$X_{1} X_{2}$ & -4.95 & 196.22 & 196.22 & 319.37 & $<0.0001^{*}$ \\
\hline$X_{1} X_{3}$ & 4.17 & 1.10 & 1.10 & 1.78 & 0.2114 \\
\hline$X_{2} X_{3}$ & 0.40 & 139.28 & 139.28 & 226.70 & $<0.0001^{*}$ \\
\hline$X_{1}^{2}$ & -0.91 & 12.02 & 12.02 & 19.56 & $0.0013^{*}$ \\
\hline$X_{2}^{2}$ & 1.39 & 27.64 & 27.64 & 45.00 & $<0.0001^{*}$ \\
\hline$X_{3}^{2}$ & -1.69 & 40.95 & 40.95 & 66.65 & $<0.0001^{*}$ \\
\hline Residual & & 6.14 & 0.61 & & \\
\hline Total & & 1168.54 & & & \\
\hline
\end{tabular}

SH5027. An evaluation of the two variables was performed while the other variable was kept at the middle level. The plots illustrated in figure 5 a indicate concentration at the high level of tween 80 (figure 5c). At the low level of yeast extract, the increase of tween 80 
concentration caused a significant decrease in enzyme production.

The optimum levels of the variables within the tested ranges for endoxylanase production were determined by using the numerical optimization panel of Design Expert software with the desirability approach. The desired goal for banana pseudostem, yeast extract and tween 80 was adjusted to the "in range" mode, while, as a response, endoxylanase production was adjusted to the "maximize" mode. Solutions were generated with desirability values that varied from 0 (undesirable response value) to 1 (completely desired response value). This suggests that the maximum endoxylanase production $(49.42 \mathrm{U} / \mathrm{mL}$ ) with a desirability value of 1.0 could occur with $15.27 \mathrm{~g} / \mathrm{L}$ banana pseudostem, $1.30 \mathrm{~g} / \mathrm{L}$ yeast extract and $0.24 \mathrm{~g} / \mathrm{L}$ tween 80 . To verify the predicted result, endoxylanase production was experimentally carried out in triplicate under optimum conditions. It was determined that the experimental value of $50.21 \mathrm{U} / \mathrm{mL}$ was very close to the predicted value. Over the last few years, various studies were performed to demonstrate the feasibility of statistical optimization methods for the enhancement of enzyme production. However, no statistical optimization studies for endoxylanase production using banana pseudostem have yet been reported.

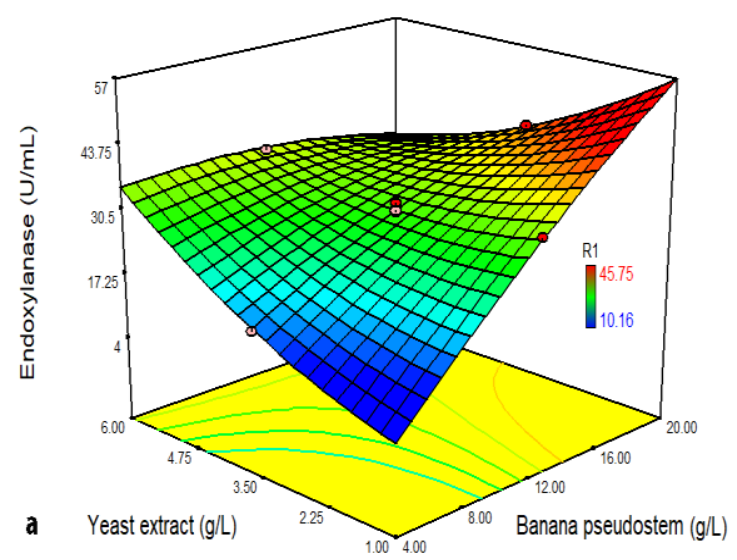

\subsection{Purification of Endoxylanase}

In the first step, the crude enzyme $(750 \mathrm{~mL})$ containing a total of $212 \mathrm{mg}$ protein and $12145 \mathrm{U} / \mathrm{mL}$ endoxylanase activity was filtered through a $30 \mathrm{kDa}$ cutoff ultrafiltration membrane to remove the lower proteins as well as increase the concentration of the others. This resulted in a yield of $93.4 \%$ and purification of 1.5-fold. No endoxylanase activity was detected in the ultrafiltrate. The retentate was further fractionized by a $50 \mathrm{kDa}$ cut-off ultrafiltration membrane, resulting in a yield of $88.4 \%$ and purification of 3.4 -fold. Finally, the dialyzed ultrafiltrate was loaded onto a DEAE Sephadex A-50 column and then eluted with $\mathrm{NaCl}$. It was determined that the enzyme was 11.2-fold purified with a $32.3 \%$ yield after the fractions (182-202), corresponding to the endoxylanase peak on the chromatogram (figure 6a), were pooled and concentrated for further SDS-PAGE and zymogram analyses. The homogeneity of the purified endoxylanase was confirmed by the visualization of a single band on the acrylamide gels through SDS-PAGE analysis. The molecular mass of the enzyme was calculated to be approximately $38 \mathrm{kDa}$ (figure 6b), which was similar to the endoxylanase from Streptomyces sp. CS428 (37 kDa) (Pradeep et al. 2013), Streptomyces

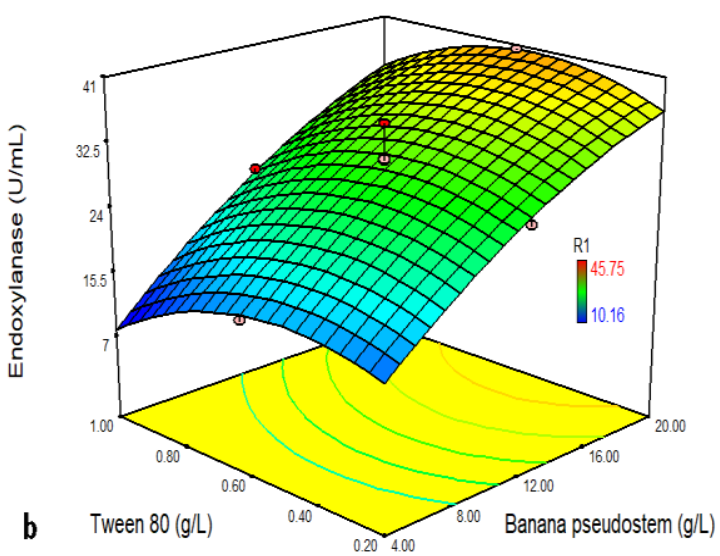

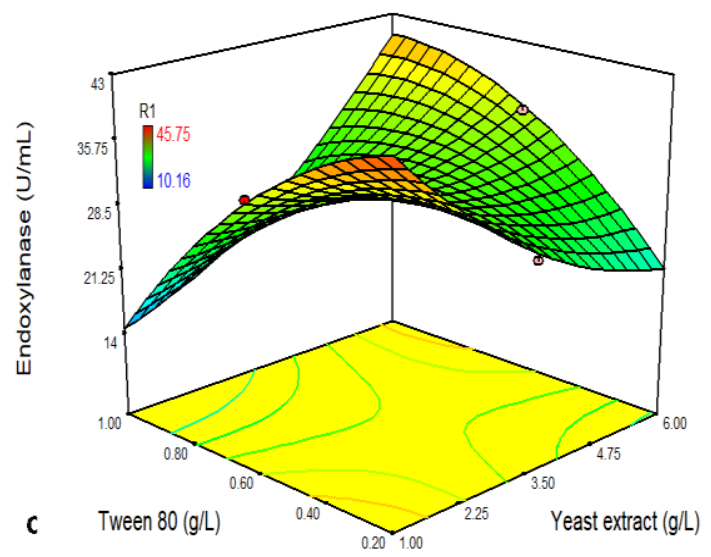

Figure 5. Response surface plots of endoxylanase production show interaction between (a) yeast extract and banana pseudostem, (b) banana pseudostem and tween 80, (c) yeast extract and banana pseudostem 
thermocyaneociolaceu (35 kDa) (Shin et al. 2009), Streptomyces sp. TN119 (35.9 kDa) (Zhou et al. 2011), Streptomyces olivaceus (42 kDa) (Sanjivkumar et al. 2017), Streptomyces sp. S9 (46 kDa) (Li et al. 2008), and Streptomyces sp. CS624 (40 kDa) (Mander et al. 2014).

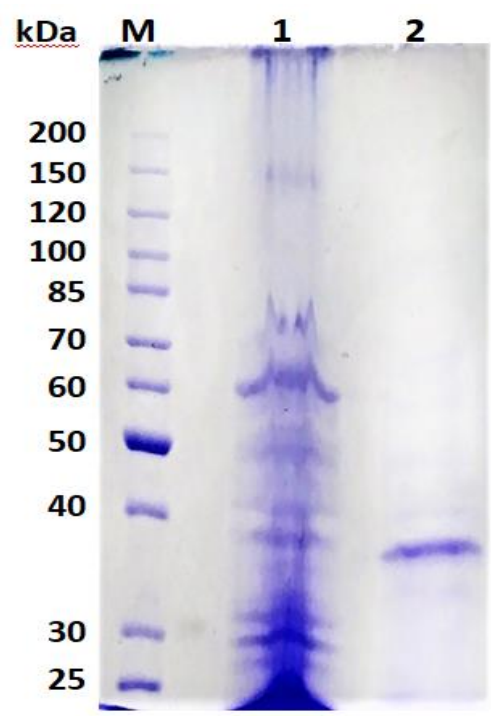

Figure 6. SDS-PAGE analysis; Lane 1: protein molecular weight marker, Lane 2: crude enzyme, Lane 3: purified endoxylanase

\subsection{Characterization of Endoxylanase}

The optimal temperature was found to be $60{ }^{\circ} \mathrm{C}$ which was similar to that of the xylanases obtained from other Streptomyces (Wang et al. 2007; Li et al. 2008; Shin et al. 2009). However, the relative activity of the endoxylanase in the present study was over $80 \%$ at 25 $60{ }^{\circ} \mathrm{C}$ (figure $7 \mathrm{a}$ ) unlike the other xylanase from Streptomyces sp. CS428 (Pradeep et al. 2013), Streptomyces megasporus DSM 41476 (Qiu et al. 2010), and Streptomyces rochei L10904 (Li et al. 2018). A significant decrease in enzyme activity was observed when the reaction temperature was decreased below 20 ${ }^{\circ} \mathrm{C}$ or increased to $70{ }^{\circ} \mathrm{C}$. However, an endoxylanase activity over $60 \%$ was recorded in both cases. The results showed that the enzyme can be used in a wide variety of biotechnological applications carried out at different temperatures. The highest enzyme activity was attained at $\mathrm{pH} 6.5$ in a $50 \mathrm{mM}$ phosphate buffer (figure $7 \mathrm{~b}$ ). However, the enzyme showed a high relative activity $(>75 \%)$ in a wide $\mathrm{pH}$ value range $(5.0-10.0)$. The relative endoxylanase activities at $\mathrm{pH} 4.5$ and 4.0 were $55.1 \%$ and $26.7 \%$, respectively. Similar pH optima ( $\mathrm{pH}$ 6.0-7.0) were previously reported for xylanases obtained from other strains such as Streptomyces sp. RCK-2010 (Kumar et al. 2012), Streptomyces flavogriseus (Pennacchio et al. 2018), and Streptomyces matensis (Yan et al. 2009).

The stability of endoxylanase at different temperatures is illustrated in Figure 8a, which reveals that the enzyme was highly stable at $40{ }^{\circ} \mathrm{C}$ and $45^{\circ} \mathrm{C}$ while the moderate stability was observed at $50{ }^{\circ} \mathrm{C}$ for 12h. Furthermore, the half-life of the enzyme was calculated as approximately $450 \mathrm{~min}, 360 \mathrm{~min}, 180 \mathrm{~min}$, $60 \mathrm{~min}, 30 \mathrm{~min}$ and $20 \mathrm{~min}$ for $55^{\circ} \mathrm{C}, 60^{\circ} \mathrm{C}, 65^{\circ} \mathrm{C}, 70^{\circ} \mathrm{C}$, $75^{\circ} \mathrm{C}$ and $80^{\circ} \mathrm{C}$, respectively. Although the reported
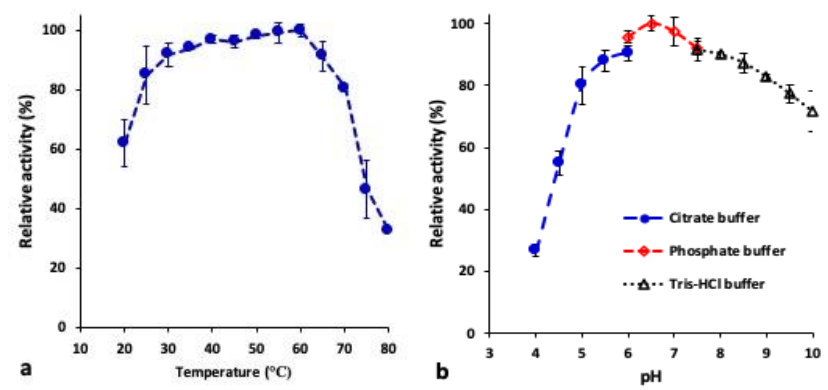

Figure 7 The effect of temperature (a) and pH (b) on the endoxylanase activity. Relative activities were expressed as a percentage of the xylanase activity and data are presented as means of three replicates with standard error (SE) bars

thermo-tolerant or thermophilic xylanase from other Streptomyces showed maximum activity at $60-65^{\circ} \mathrm{C}$, the endoxylanase present in this study was more stable at 30-70 ${ }^{\circ} \mathrm{C}$ (Nascimento et al. 2002; Yan et al. 2009; Qiu et al. 2010; Liu et al. 2013). Similar to the endoxylanase results previously reported from other Streptomyces, the results of this study showed that endoxylanase was more stable at $\mathrm{pH} 6.0-7.5$ for $12 \mathrm{~h}$ at $60{ }^{\circ} \mathrm{C}$ (figure $8 \mathrm{~b}$ ). The enzyme retained active more than $50 \%$ of its activity at pH 5.0-9.0 for an hour. Therefore, the enzyme has a huge potential for various industrial applications such as the enhancement of dough, hydrolysis of lignocelluloses and deinking.
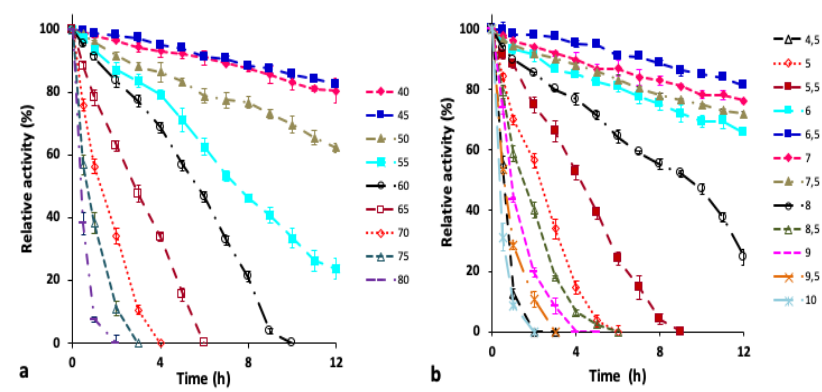

Figure 8 The stability of the enzyme in different temperatures (a) and $\mathrm{pH}$ (b) for $12 \mathrm{~h}$

Storage stability, which is one of the most important properties of an enzyme for industrial applications, was investigated at -20 and $+4{ }^{\circ} \mathrm{C}$. The results showed that the enzyme could be stored at $-20^{\circ} \mathrm{C}$ for more than 180 days. On the other hand, the relative activity of the enzyme decreased to approximately $50 \%$ within the first 30 days.

Among the investigated metal ions, $\mathrm{Mg}^{+2}$ and $\mathrm{Ca}^{+2}$ caused slight enhancement in endoxylanase activity while a significant decrease was observed by the preincubation of the enzyme with $\mathrm{Cu}^{+2}$ and $\mathrm{Hg}^{+2}$ for $120 \mathrm{~min}$. Considering the results of the structural xylanase studies previously reported, the activation of the enzyme by $\mathrm{Ca}^{+2}$ may be due to glutamate residues at the active site ( $\mathrm{Li}$ et al. 2008; Kui et al. 2010) and strong inactivation by $\mathrm{Hg}^{+2}$ may be due to the oxidation of the indole ring of tryptophan amino acid present in the catalytic domain close the active site (Kui et al. 2010). A significant enhancement in enzyme activity was observed with the pre-incubation of the enzyme with methanol for $60 \mathrm{~min}$. Furthermore, the relative activity of the enzyme slightly increased with ethanol, isopropanol, and ethyl acetate. 
However, dimethyl sulfoxide (DMSO) and dimethylformamide (DMF) exhibited a slight inhibitory effect on the enzyme while sodium dodecyl sulfate (SDS) and 1,4-dithiothreitol (DTT) significantly inhibited endoxylanase activity in a time-dependent manner. A very low inhibitory effect of ethylenediaminetetraacetic acid (EDTA) on endoxylanase activity showed that the enzyme did not need metal ions for activity (Gilead and Shoham 1995). Surprisingly, complete inhibition in the enzyme activity was detected by 2-mercaptoethanol at the end of the $120 \mathrm{~min}$ incubation period unlike most of the other reported studies (Carvalho et al. 2017; Kumar and Shukla 2018).

The endoxylanase showed the highest specificity towards oat spelt xylan (115.70\%). The hydrolytic activity of the enzyme on beechwood xylan with $98.87 \%$ relative activity was very close to birchwood xylan. However, the enzyme did not show any activity towards CMC, filter paper, soluble starch, or citrus pectin. The kinetic parameters $K_{m}$ and $V_{\max }$ of the endoxylanase were studied using various concentrations of birchwood xylan $(0.5-20 \mathrm{mg} / \mathrm{mL})$. The $K_{m}$ and $V_{\max }$ values estimated by the Lineweaver-Burk reciprocal plot were 1.689 $\mathrm{mg} / \mathrm{mL} . \mathrm{min}$ and $23.17 \mu \mathrm{mol} / \mathrm{min} . \mathrm{mg}$, respectively. The lower $K_{m}$ value of the endoxylanase present in this study suggested that it had much more affinity on birchwood xylan than xylanases produced by other Streptomyces species (Pradeep et al. 2013; Zhou et al. 2011; Mander et al. 2014; Qiu et al. 2010; Ninawe et al. 2008; Li et al. 2012; Adıgüzel and Tunçer 2016;). This property of the enzyme indicates that endoxylanase from Streptomyces sp. SH5027 is exceptional for many industrial applications.

\subsection{Application of Endoxylanase in Bread Making}

The results presented in Figure 9 showed that the endoxynalase from Streptomyces sp. SH5027 improved the specific volume of bread. Increases in the specific volumes were $9.6 \%, 12.8 \%$, and $16.8 \%$ when $200 \mathrm{U}, 300$ $\mathrm{U}$, and $400 \mathrm{U}$ endoxylanase was added to the flour per $\mathrm{kg}$. An increase in the bread's specific volume may be due to the decrease in un-extractable xylan which can hold water 10-fold than its mass as reported earlier (Courtin and Delcour 2002).

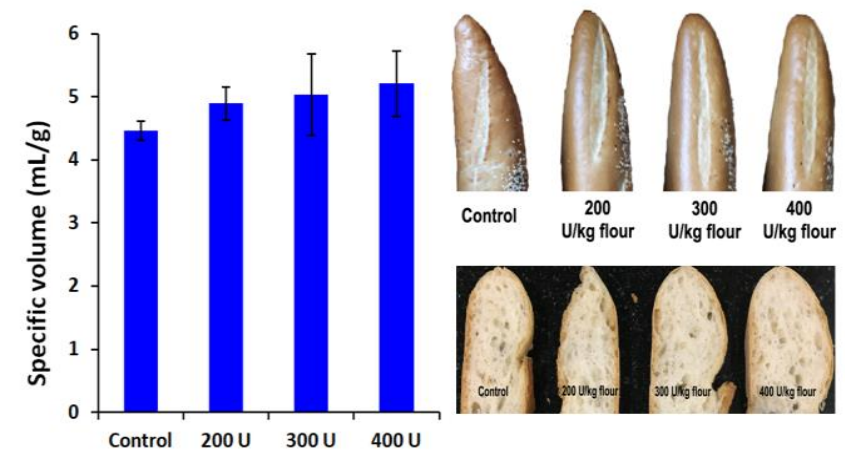

Figure 9. The specific volumes of breads prepared with and without endoxylanase

\section{CONCLUSION}

The present study showed that Streptomyces sp. SH5027, which was newly isolated from soil contaminated with banana wastes and identified based on 16S rRNA gene sequences, can produce endoxylanase by using banana pseudostem as the carbon source. The optimization studies on endoxylanase production by Streptomyces sp. SH5027, conducted using the OFAT and RSM approaches, were found to be an effective tool to increase the yield approximately 7 -fold and decrease the production cost. This study also presents a sustainable solution for the disposal problems of banana wastes. The superior biochemical features of the enzyme, such as thermostability, wide $\mathrm{pH}$ stability range, organic solvent stability, and high affinity to substrate make it a promising candidate for many biotechnological applications. In conclusion, the use of endoxylanase in bread making increased the specific volume of bread.

\section{Conflicts of interest}

The authors declare no conflicts of interest.

\section{REFERENCES}

Adıgüzel A 0 (2020). Production and characterization of thermo-, halo-and solvent-stable esterase from Bacillus mojavensis TH309. Biocatalysis and Biotransformation, 38(3), 210-226.

Adigüzel A O \& Tunçer M (2016). Production, characterization and application of a xylanase from Streptomyces sp. AOA40 in fruit juice and bakery industries. Food Biotechnol, 30(3), 189-218.

Adıgüzel A 0 \& Tunçer M (2017a). Production, purification, characterization and usage of a detergent additive of endoglucanase from isolated halotolerant Amycolatopsis cihanbeyliensis mutated strain Mut43. Biocatalysis and Biotransformation, 35(3), 197-204.

Adıgüzel A 0 \& Tunçer M (2017b). Production and characterization of partially purified thermostable endoxylanase and endoglucanase from novel Actinomadura geliboluensis and the biotechnological applications in the saccharification of lignocellulosic biomass. BioResources, 12(2), 2528-2547.

Ahamed A \& Vermette P (2008). Culture-based strategies to enhance cellulase enzyme production from Trichoderma reesei RUT-C30 in bioreactor culture conditions. Biochem Eng J, 40(3), 399-407.

Alvindia D G \& Natsuaki K T (2009). Biocontrol activities of Bacillus amyloliquefaciens DGA14 isolated from banana fruit surface against banana crown rotcausing pathogens. Crop Prot, 28(3), 236-242.

Bradford M M (1976). A rapid and sensitive method for the quantitation of microgram quantities of protein utilizing the, principle of protein-dye binding. Anal Biochem, 72, 248-254.

Carvalho E A, dos Santos Góes L M, Uetanabaro A P T, da Silva E G P, Rodrigues L B, Pirovani C P \& da Costa A $M$ (2017). Thermoresistant xylanases from Trichoderma stromaticum: Application in bread making and manufacturing xylo-oligosaccharides. Food Chem, 221, 1499-1506.

Courtin C M \& Delcour J A (2002). Arabinoxylans and endoxylanases in wheat flour bread-making. J Cereal Sci, 35(3), 225-243. 
Food and Agriculture Organization. (2017). Banana statistical compendium. FAO, http://www.fao.org/fileadmin/templates/est/COM M_MARKETS_MONITORING/Bananas/Documents/B anana_Statistical_Compendium_2017.pdf

Gabhane J, William S P, Gadhe A, Rath R, Vaidya A N \& Wate S (2014). Pretreatment of banana agricultural waste for bio-ethanol production: Individual and interactive effects of acid and alkali pretreatments with autoclaving, microwave heating and ultrasonication. Waste Manage, 34(2), 498-503.

Gilead S \& Shoham Y (1995). Purification and characterization of alpha-L-arabinofuranosidase from Bacillus stearothermophilus T-6. Appl Environ Microbiol, 61(1), 170-174.

Houfani A A, Větrovský T, Baldrian P \& Benallaoua S (2017). Efficient screening of potential cellulases and hemicellulases produced by Bosea sp. FBZP-16 using the combination of enzyme assays and genome analysis. World J Microbiol Biotechnol, 33(29), 1-14.

Kui H, Luo H, Shi P, Bai Y, Yuan T, Wang Y, Yang P, Dong S \& Yao B (2010). Gene cloning, expression, and characterization of a thermostable xylanase from Nesterenkonia xinjiangensis CCTCC AA001025. Appl Biochem Biotechnol, 162(4), 953-965.

Kumar A, Gupta R, Shrivastava B, Khasa Y P \& Kuhad R C (2012). Xylanase production from an alkalophilic actinomycete isolate Streptomyces sp. RCK-2010, its characterization and application in saccharification of second generation biomass. J Mol Catal B: Enzym, 74(3-4), 170-177.

Kumar V \& Satyanarayana T (2012). Thermo-alkalistable xylanase of a novel polyextremophilic Bacillus halodurans TSEV1 and its application in biobleaching. Int Biodeterior Biodegradation 75:138-145.

Kumar V \& Shukla P (2018). Extracellular xylanase production from T. lanuginosus VAPS24 at pilot scale and thermostability enhancement by immobilization. Process Biochem, 71, 53-60.

Li N, Meng K, Wang Y, Shi P, Luo H, Bai Y, Yang P \& Yao B (2008). Cloning, expression, and characterization of a new xylanase with broad temperature adaptability from Streptomyces sp. S9. Appl Microbiol Biotechnol, $80(2), 231$.

Li Q, Sun B, Li X, Xiong K, Xu Y, Yang R, Hou J \& Teng C (2018). Improvement of the catalytic characteristics of a salt-tolerant GH10 xylanase from Streptomyces rochei L10904. Int J Biol Macromol, 107, 1447-1455.

Li X, Li E, Zhu Y, Teng C, Sun B, Song H \& Yang R (2012). A typical endo-xylanase from Streptomyces rameus L2001 and its unique characteristics in xylooligosaccharide production. Carbohydr Res, 359, 30-36.

Liu Z, Zhao X \& Bai F (2013). Production of xylanase by an alkaline-tolerant marine-derived Streptomyces viridochromogenes strain and improvement by ribosome engineering. Appl Microbiol Biotechnol, 97(10), 4361-4368.

Maheswari M U \& Chandra T S (2000). Production and potential applications of a xylanase from a new strain of Streptomyces cuspidosporus. World J Microbiol Biotechnol, 16(3), 257-263.
Mander P, Choi Y H, Pradeep G C, Choi Y S, Hong J H, Cho S \& Yoo J C (2014). Biochemical characterization of xylanase produced from Streptomyces sp. CS624 using an agro residue substrate. Process Biochem 49(3), 451-456.

Miller GL (1959) Use of dinitrosalisylic acid reagent for determination of reducing sugar. Anal Chem, 31, 426428.

Nascimento R P, Coelho R R R, Marques S, Alves L, Girio F M, Bon E P S \& Amaral-Collaço M T (2002). Production and partial characterisation of xylanase from Streptomyces sp. strain AMT-3 isolated from Brazilian cerrado soil. Enzyme Microb Technol, 31(4), 549-555.

Ninawe S, Kapoor M \& Kuhad R C (2008). Purification and characterization of extracellular xylanase from Streptomyces cyaneus SN32. Bioresour Technol, 99(5), 1252-1258.

Padam B S, Tin H S, Chye F Y \& Abdullah M I (2014). Banana by-products: an under-utilized renewable food biomass with great potential. J Food Sci Technol, 51(12), 3527-3545.

Pennacchio A, Ventorino V, Cimini D, Pepe O, Schiraldi C, Inverso M \& Faraco V (2018). Isolation of new cellulase and xylanase producing strains and application to lignocellulosic biomasses hydrolysis and succinic acid production. Bioresour Technol 259, 325-333.

Porsuk I, Özakın S, Bali B \& Yilmaz E I (2013). A cellulasefree, thermoactive, and alkali xylanase production by terrestrial Streptomyces sp. CA24. Turkish J Biol 37(3):370-375.

Pradeep G C, Choi Y H, Choi Y S, Seong C N, Cho S S, Lee H J \& Yoo J C (2013). A novel thermostable cellulase free xylanase stable in broad range of $\mathrm{pH}$ from Streptomyces sp. CS428. Process Biochem, 48(8), 1188-1196.

Qiu Z, Shi P, Luo H, Bai Y, Yuan T, Yang P, Liu S \& Yao B (2010). A xylanase with broad $\mathrm{pH}$ and temperature adaptability from Streptomyces megasporus DSM 41476, and its potential application in brewing industry. Enzyme Microb Technol, 46(6), 506-512.

Sanjivkumar M, Silambarasan T, Palavesam A, Immanuel $G$ (2017). Biosynthesis, purification and characterization of $\beta-1,4$-xylanase from a novel mangrove associated actinobacterium Streptomyces olivaceus (MSU3) and its applications. Protein Expr Purif, 130, 1-12.

Shah M P, Reddy G V, Banerjee R, Babu P R \& Kothari I L (2005). Microbial degradation of banana waste under solid state bioprocessing using two lignocellulolytic fungi (Phylosticta spp. MPS-001 and Aspergillus spp. MPS-002). Process Biochem, 40(1), 445-451.

Sharma S \& Bajaj B K (2018). Xylanase production from a new strain of Aspergillus terreus S9 and its application for saccharification of rice straw using combinatorial approach. Environ Prog Sustain, 37(3), 1210-1219.

Shin J H, Choi J H, Lee O S, Kim Y M, Lee D S, Kwak Y Y, Kim W C \& Rhee I K (2009). Thermostable xylanase from Streptomyces thermocyaneoviolaceus for optimal production of xylooligosaccharides. Biotechnol Bioprocess Eng, 14(4), 391-399.

Su Y, Zhang X, Hou Z, Zhu X, Guo X \& Ling P (2011). Improvement of xylanase production by thermophilic 
fungus Thermomyces lanuginosus SDYKY-1 using response surface methodology. N Biotechnol, 28(1), 40-46.

Thomas L, Sindhu R \& Pandey A (2013). Identification and characterization of a highly alkaline and thermotolerant novel xylanase from Streptomyces sp. Biologia, 68(6), 1022-1027.

Vieira W B, Moreira L R S, Neto A M \& Filh E X F (2007). Production and characterization of an enzyme complex from a new strain of Clostridium thermocellum with emphasis on its xylanase activity. Braz J Microbiol, 38, 237-242.

Walia A, Guleria S, Mehta P, Chauhan A \& Parkash J (2017). Microbial xylanases and their industrial application in pulp and paper biobleaching: a review. 3 Biotech, 7(1), 11.

Wang Y, Zhang H, He Y, Luo H \& Yao B (2007). Characterization, gene cloning, and expression of a novel xylanase XYNB from Streptomyces olivaceoviridis A1. Aquaculture 1(267), 328-334.

Yabalak E, Adigüzel S K, Adıgüzel A O, Ergene R S, Tuncer, M \& Gizir A M (2017). Application of response surface methodology for the optimization of oxacillin degradation by subcritical water oxidation using $\mathrm{H}_{2} \mathrm{O}_{2}$ : genotoxicity and antimicrobial activity analysis of treated samples. Desalination and Water Treatment, 81, 186-198.

Yan Q, Hao S, Jiang Z, Zhai Q \& Chen W (2009). Properties of a xylanase from Streptomyces matensis being suitable for xylooligosaccharides production. J Mol Catal B: Enzym, 58(1-4), 72-77.

Zhou J, Shi P, Zhang R, Huang H, Meng K, Yang P \& Yao B (2011). Symbiotic Streptomyces sp. TN119 GH 11 xylanase: a new pH-stable, protease-and SDSresistant xylanase. J. Ind. Microbiol Biotechnol, 38(4), 523-530.

(c) Author(s) 2022.

This work is distributed under https://creativecommons.org/licenses/by-sa/4.0/ 